\title{
Pedological Characterisation of Soils of University Farm, Federal University of Kashere, Gombe State, Nigeria
}

\author{
Salem $\mathrm{A}^{1 *}$, Sani IA ${ }^{1}$, Iliya $\mathrm{DB}^{1}$ and Musa $\mathrm{SA}^{2}$
}

${ }^{1}$ Department of Soil Science, Federal University of Kashere, Gombe State, Nigeria

${ }^{2}$ Deparment of Soil Science, Modibbo Adama University of Technology Yola, Adamawa State, Nigeria

*Corresponding author: Salem A

Abstract

Pedological characterization of soils is key for land resource planning and development of soil management interventions for improving agricultural productivity. A study was conducted in University Farm to examine soil morphological, physical and chemical attributes for land use planning and determining area specific soil management strategies. A detailed soil survey was conducted using a free survey method. Three profile pits were dug at the upper, middle and lower slope positions. Hoe and hand trowel was used in collecting soil samples from identified genetic horizons. The collected soil samples were then air-dried, crushed gently and stored in well labeled polythene bags. The processed soil samples were then taken to the laboratory for analysis following standard procedure to determine the physical and chemical properties of each soil sample. The results indicated that the soils are deep to very deep and most of the soils are predominantly weak-red to pale-red in colour $(7.5 \mathrm{R} 4 / 3-10 \mathrm{R} 7 / 3)$, while soil structure is observed to be dominantly sub-angular blocky in all the profiles. The dry, moist and wet consistencies across slope were predominantly hard soft, friable, non-sticky non plastic, slightly sticky and slightly plastic respectively. The result of the soil particle size distribution indicated that the values of sand, silt and clay ranged from $17.6 \%$ to $69.6 \%$ $($ mean $=46.26 \%), 6.40 \%$ to $64.4 \%($ mean $=39.3 \%)$ and $12 \%$ to $26 \%($ mean $=16.43 \%)$ respectively. The soils were generally found to be sandy loamy to silty-loamy in texture, while bulk density value was found to be low ranging from 1.19 to $1.66 \mathrm{~g} / \mathrm{cm}^{3}$. The mean $\mathrm{pH}$ ranged from $5.52-5.73$ and termed to be moderately acidic in reaction. The mean organic carbon, total nitrogen and available phosphorus content obtained in this study ranged from 0.27 $0.33 \mathrm{mg} / \mathrm{kg}, 0.02-0.03 \mathrm{~g} / \mathrm{kg}$ and $6.82-6.94 \mathrm{mg} / \mathrm{kg}$ respectively. The exchangeable bases $(\mathrm{Ca}, \mathrm{Mg}, \mathrm{K}$ and $\mathrm{Na})$ were generally found to be medium to high. Management practices such as mulching cover cropping, alley cropping, addition of organic and green manures, chemical fertilizers containing especially NP, and K should be adopted for optimal agricultural productivity.

Keywords: Characterization, Exchangeable Bases, Genetic Horizon, Mulching, Pedological.

Copyright @ 2020: This is an open-access article distributed under the terms of the Creative Commons Attribution license which permits unrestricted use, distribution, and reproduction in any medium for non-commercial use (NonCommercial, or CC-BY-NC) provided the original author and source are credited.

\section{INTRODUCTION}

Agriculture plays a significant role in the economy and livelihoods of people in Nigeria. Improving the productivity of the agriculture sector of the country is greatly dependent on efficient utilization and management of soils [1]. Sustainable utilization of agricultural lands requires a thorough knowledge and inventory of soil resources and hence there is need to characterize soils in farming areas [2]. Soil characterization helps to generate information which is required for land use planning and soil management purposes. Soil surveys are important for soil characterization and classification purposes and aids in the creation of data bases on soil morphology, physical and chemical properties [3]. This information is important for determining agricultural potentials, limitations and possible management options for the soils in a particular area thereby helping in selection of the best agricultural enterprises suitable for that area [4, 5]. Irrigation projects can be planned and developed based on information obtained from soil characterization and classification. Area specific soil fertility management strategies, aimed at increasing crop production, can be developed for a particular area using soil survey data instead of using general fertilizer recommendations. Information on soil characterization can be utilized widely by land use planners, agriculture researchers, extension staff, development agents and farmers in order to sustainably increase agriculture production. 
Agricultural researches play an integral part in the study area and yet there have been no detailed soil survey studies conducted to characterize the soils in this area. There is limited information available for assessing agricultural potential and limitations of the soils in the study area and hence there is need to conduct detailed soil surveys for soil characterization purposes. Therefore the objectives of the study were to characterize the soils of the study area by determining their soil morphology, physical and chemical attributes, thereby generating soils information required for land use planning and soil management strategies in the study area.

\section{MATERIALS AND METHODS}

\section{The study area}

The field experiment was conducted at University Farm Federal University of Kashere, Gombe State. Its coordinates lie between latitude $\left(10^{\circ} 30^{1} \mathrm{~N}\right)$ and longitude $\left(10^{\circ} 52^{1} \mathrm{E}\right)$, on the Northern fringes of the Sudan Savanna belt of Nigeria. It is located at an elevation of $523 \mathrm{~m}$ above sea level. The geology of the study area is developed on basement complex rocks with adjoining sedimentary rocks formation [6]. The area has a tropical climate, with distinct wet and dry season [7]. The area records about three to four months of rainfall and is concentrated in the months of July, August and September with the average annual rainfall of $951 \mathrm{~mm}$ per annum [8]. The mean annual temperature ranged from $30-37^{\circ} \mathrm{C}$, while March April and May were observed to be the dry hot months of the year. During the rainy season, the temperature drops considerably due to the cloud cover between July and August as well as during the Harmatttan periods of November to February [8].

\section{Soil sampling and handling}

Three profile pits, with dimensions $2 \mathrm{~m}$ long, $1.5 \mathrm{~m}$ wide, and $1.5 \mathrm{~m}$ deep, were dug along a toposequence at the study site. Soil samples and soil clods were collected from each identified genetic horizons of the three profile pits, using hoe and hand trowel. The collected Soil samples were then properly labeled in polythene bags and taken to the laboratory for analysis.

In the laboratory, each sample was separately air dried ground and passed through a $2 \mathrm{~mm}$ sieve for laboratory analysis as described by [9]. Particle size analysis was determined using the Bouyoucos hydrometer method, after dispersing the soil samples with 5\% Sodium hexametaphosphate. The bulk density was determined by the clod method [10]. Soil pH was determined in 1:1 water ratio using a glass electrode $\mathrm{pH}$ metre [11]. Determination of Organic carbon, and Total nitrogen were done by the wet oxidation method and regular micro-kjeldal method respectively. Available phosphorus was determined using the Bray 1 method. The exchangeable cations in the soil samples were determined in the extract of $1 \mathrm{~N}$ neutral ammonium acetate $\left(\mathrm{NH}_{4} \mathrm{OA}_{\mathrm{C}}\right)[12]$.

\section{DATA ANALYSIS}

The data generated from laboratory analysis were subjected to simple descriptive statistic which include range and mean as described by [13], while means were compared using Coefficient of variation [14].

\section{RESULTS AND DISCUSSION \\ Morphological properties of soils of study area}

Soil depths varied across the toposequence, with profile depth across the slope ranged from 148 to $200 \mathrm{~cm}$. The profile at the lower slope recorded the shallower depth, but generally the soils were found to be very deep [15-17], all reported deep to very deep soil depth in their various studies. The depth of all the soil profiles will permit crop roots proliferation and elongation since the water table is low enough not to constitute an obstacle to root development. The soils in the surface horizons ranged from brown (10YR), red (7.5R 4/3) and red (10R 7/3) across the toposequence, while the corresponding subsurface colour were found to be predominantly brown (10YR) to red (10R 7/3) in colour. Hydromorphic mottling was also observed in only the subsurface horizons and is majorly few and faint. The kind, amount and distribution of organic matter, various mineral constituents, mainly iron compounds and or stagnant water table cause soils to appear in different colours $[18,19]$. The surface horizon is predominantly found to be Sandy loam in texture, while the subsurface horizons were dominated by Sandy loam and Silty loam textures. The texture of these soils reflected the parent rocks from which they are formed [20]. Several authors linked soil texture to the nature of parent materials from which the soils were derived and also to the rate and nature of some weathering processes [21]. The soil structure is dominantly sub-angular blocky ranging from weak to moderate in grade across the profiles. These confirm earlier findings of [22] who reported both weak to moderate subangular to angular soil structure in their various studies. The dry, moist and wet consistencies across slope were predominantly hard $(\mathrm{H})$ to soft $(\mathrm{S})$, friable (F) and non-sticky non plastic (nsnp) to slightly sticky and slightly plastic (sssp) across the profiles [23], also reported similar findings in some pedons, while characterizing and classifying soils of Yikalo Subwatershed in Lay Gayint District, Northwestern Highlands of Ethiopia. Generally the increased sticky consistence (wet) with increase in soil depth observed in some profile is a diagnostic of clay lessivation, as reported by [24] for soils developed in sedimentary basins [22], also reported increase in stickness and hardness down the profile.

In all the profiles studied, few and fine roots were found to predominate in both surface and subsurface horizons. Generally the content of roots 
decreased as depth increases. Many roots were found in the Ap horizons since it is the zone of active root activities. Horizon boundaries were mostly found to be gradual and wave (gw) in all the studied pedons. Horizonation is ascribed to addition, losses, translocation and transformation of organic matter and colour development, very evident for soils under vegetational condition. Generally horizonation is promoted in the soils by melanization from the humification of organic matter in the A horizon.

Table-1: Morphological properties of the pedons of study area

\begin{tabular}{|c|c|c|c|c|c|c|c|c|c|c|c|c|}
\hline \multirow[t]{2}{*}{ Pedon } & \multirow[t]{2}{*}{$\begin{array}{l}\text { Horizon } \\
\text { Designation } \\
\end{array}$} & \multirow{2}{*}{$\begin{array}{l}\begin{array}{l}\text { Horizon } \\
\text { Depth }\end{array} \\
(\mathrm{cm}) \\
\end{array}$} & \multirow{2}{*}{$\begin{array}{l}\text { Munsell } \\
\text { (Dry) } \\
\end{array}$} & \multirow{2}{*}{$\begin{array}{l}\text { color } \\
\text { (moist) }\end{array}$} & \multirow{2}{*}{$\begin{array}{l}\text { Mottle } \\
\text { colour }\end{array}$} & \multirow[t]{2}{*}{$\begin{array}{l}\text { Tex. } \\
\text { Class } \\
\end{array}$} & \multirow[t]{2}{*}{ Structure } & \multicolumn{3}{|c|}{ Consistence } & \multirow[t]{2}{*}{ Boundary } & \multirow[t]{2}{*}{ Inclusions } \\
\hline & & & & & & & & Wet & Moist & Dry & & \\
\hline \multicolumn{13}{|c|}{ Upper Slope } \\
\hline \multirow[t]{5}{*}{ P1 } & Ap & $0-15$ & $\begin{array}{l}10 \mathrm{YR} \\
6 / 2\end{array}$ & $\begin{array}{l}10 \mathrm{YR} \\
4 / 2\end{array}$ & - & SL & Wmsbk & Nsnp & $\mathrm{F}$ & $\mathrm{S}$ & $\mathrm{Cw}$ & $\mathrm{mm}$ \\
\hline & Bwg1 & $15-42$ & $\begin{array}{l}10 \mathrm{YR} \\
6 / 2\end{array}$ & $\begin{array}{l}10 \mathrm{YR} \\
4 / 3\end{array}$ & - & SL & Wmsbk & Nsnp & $\mathrm{F}$ & $\mathrm{H}$ & Gw & ff \\
\hline & Bwg2 & $42-83$ & $\begin{array}{l}10 \mathrm{YR} \\
8 / 1 \\
\end{array}$ & $\begin{array}{l}10 \mathrm{YR} \\
7 / 2 \\
\end{array}$ & - & SL & Wmsbk & Nsnp & $\mathrm{VF}$ & $\mathrm{S}$ & $\mathrm{Gw}$ & ff \\
\hline & Bwg3 & $83-114$ & $\begin{array}{l}10 \mathrm{YR} \\
7 / 2\end{array}$ & $\begin{array}{l}10 \mathrm{YR} \\
5 / 3\end{array}$ & Ff & SL & Wmsbk & Nsnp & $\mathrm{F}$ & $\mathrm{L}$ & Gw & - \\
\hline & $\mathrm{Cg}$ & $114-200$ & $\begin{array}{l}\text { 10YR } \\
8 / 1\end{array}$ & 10YR8/2 & $\mathrm{Ff}$ & SL & Wmsbk & Nsnp & VF & $\mathrm{S}$ & - & - \\
\hline \multicolumn{13}{|c|}{ Middle Slope } \\
\hline \multirow[t]{5}{*}{ P2 } & Ap & $0-31$ & $\begin{array}{l}7.5 \mathrm{YR} \\
5 / 4\end{array}$ & $\begin{array}{l}7.5 \mathrm{YR} \\
3 / 4\end{array}$ & - & SL & Wmsbk & Nsnp & $\mathrm{L}$ & $\mathrm{S}$ & Gw & ff \\
\hline & Bwg1 & $31-68$ & $10 \mathrm{R} 4 / 2$ & $10 \mathrm{R} 3 / 2$ & - & $\mathrm{SiL}$ & msbk & Sssp & $\mathrm{F}$ & $\mathrm{S}$ & $\mathrm{Gw}$ & $\mathrm{ff}$ \\
\hline & Bwg2 & $68-112$ & $10 \mathrm{R} 6 / 3$ & $10 \mathrm{R} 4 / 2$ & Ff & SL & Wmsbk & Nsnp & $\mathrm{L}$ & $\mathrm{S}$ & $\mathrm{Gw}$ & \\
\hline & Bwg3 & $112-149$ & $10 \mathrm{R} 8 / 2$ & $10 \mathrm{R} 7 / 3$ & $\mathrm{Ff}$ & SL & Wmsbk & Nsnp & $\mathrm{F}$ & & $\mathrm{Cw}$ & \\
\hline & $\mathrm{Cg}$ & $149-200$ & $10 \mathrm{R} 7 / 3$ & $10 \mathrm{R} 8 / 4$ & Cmd & SiL & $\mathrm{msbk}$ & Sssp & $\mathrm{F}$ & $\mathrm{H}$ & - & \\
\hline \multicolumn{13}{|c|}{ Lower Slope } \\
\hline \multirow[t]{4}{*}{$\mathbf{P 3}$} & Ap & $0-17$ & $10 \mathrm{R} 6 / 4$ & $10 \mathrm{R} 3 / 4$ & & $\mathrm{~L}$ & msbk & Nsnp & VF & $\mathrm{H}$ & Gw & ff \\
\hline & Bwg1 & $17-58$ & $10 \mathrm{R} 5 / 3$ & $10 \mathrm{R} 4 / 3$ & Ff & $\mathrm{SiL}$ & msbk & Sssp & $\mathrm{F}$ & $\mathrm{H}$ & Gw & $\mathrm{ff}$ \\
\hline & Bwg2 & $58-112$ & $10 \mathrm{R} 7 / 2$ & $10 \mathrm{R} 5 / 3$ & $\mathrm{Ff}$ & $\mathrm{SiL}$ & msbk & Sssp & $\mathrm{F}$ & $\mathrm{H}$ & $\mathrm{Cw}$ & $\mathrm{Cm}$ \\
\hline & $\mathrm{Cg}$ & $112-148$ & $10 \mathrm{R} 8 / 2$ & $10 \mathrm{R} 6 / 3$ & Cсp & $\mathrm{L}$ & msbk & Nsnp & $\mathrm{F}$ & $\mathrm{H}$ & - & $\mathrm{Cc}$ \\
\hline
\end{tabular}

Key Color: Lbg = light brownish grey, Dgb = dark grey brown, $\mathrm{Plb}=$ pale brown, $\mathrm{B}=$ brown, $\mathrm{W}=$ white, $\mathrm{Lg}=$ light grey, $\mathrm{Vplb}=$ very pale brown, $\mathrm{Wkr}=$ weak red, $\mathrm{Dkr}=$ dusk red, $\mathrm{Plr}=$ pale red, $\mathrm{Pkw}$ pinkish $=$ white, $\mathrm{P}=$ Pink.

Mottles: $\mathrm{ff}=$ few faint, cmd $=$ common medium distinct, $\mathrm{ccp}=$ common coarse prominent.

Texture: $\mathrm{S}=$ sand, $\mathrm{C}=$ clay, $\mathrm{Si}=$ silt, $\mathrm{L}=$ loam, $\mathrm{SL}=$ sandy loam, $\mathrm{SCL}=$ sandy clay loam, $\mathrm{SiL}=$ silty loam, $\mathrm{SiC}=$ silty clay, $\mathrm{LS}=$ loamy sand.

Structure: $\mathrm{Wmg}=$ weak medium granular, $\mathrm{Mm}=$ moderate medium, Sbk = sub-angular blocky, $\mathrm{Wm}=$ weak medium, Wf $=$ Weak firm, Wfg = weak firm granular, $\mathrm{Sc}=$ soft coarse, $\mathrm{Sm}=$ strong medium

Consistence: $\mathrm{S}=$ soft, $\mathrm{F}=$ firm, $\mathrm{L}=$ loose, $\mathrm{H}=$ hard, Vf $=$ very friable, $\mathrm{ns}=$ non sticky, $\mathrm{np}=$ non plastic, $\mathrm{ss}=$ slightly sticky, $\mathrm{sp}=$ slightly plastic.

Roots: $\mathrm{mm}=$ many medium, $\mathrm{ff}=$ few fine, $\mathrm{cm}=$ common medium, $\mathrm{cc}=$ common concretions.

Horizon boundary: $\mathrm{cw}=$ clear wavy, $\mathrm{gw}=$ gradual wavy.

\section{Physical properties of soils of study area}

Sand fractions dominated the particle size distributions in most profiles (Upper and Middle slopes) which ranged from $17.6 \%$ to $69.6 \%$ (mean=46.26\%). The particle size distribution showed that the sand content were the highest and the clay content were the lowest for most of the profiles as shown from the result in Table 2. The predominance of Sand particles in arid and semi-arid climates is not uncommon because many of them were formed from aeolian deposits blown from across several thousands of kilometers [25]. The percentage of silt content ranged from $6.40 \%$ to $64.4 \%$ (mean $=39.3 \%$ ). The highest value of $64.4 \%$ was recorded in the lower slope. A notable feature in all the soils studied is their high silt content (Tables 2) [26, 27] all reported higher Silt content in their various studies. This high Silt content obtained in this study could be attributed to the nature of parent material and stage of soil development [28]. The clay content ranges from $12 \%$ to $26 \%($ mean $=16.43 \%)$ in all the pedons. The highest value of $30 \%$ was recorded at the lower slope $[29,30]$, also reported low values of Clay content in their various studies while working on similar type of soils. The low clay content obtained in this study is attributed to the fact that the parent material of the study area is rich in sand. 
Table-2: Physical properties of soils of study area

\begin{tabular}{|c|c|c|c|c|c|}
\hline $\begin{array}{l}\text { Depth } \\
\text { (cm) }\end{array}$ & Sand & $\begin{array}{c}\text { Clay } \\
\longrightarrow(\%)\end{array}$ & Silt & Textural Class & BD $\left(\mathrm{g} / \mathrm{cm}^{3}\right)$ \\
\hline & & Upper Slope & & & \\
\hline $0-15$ & 69.6 & 14.0 & 16.4 & Sandy loam & 1.52 \\
\hline $15-42$ & 69.6 & 13.0 & 17.4 & Sandy loam & 1.48 \\
\hline $42-83$ & 69.6 & 12.0 & 18.4 & Sandy loam & 1.52 \\
\hline $83-114$ & 69.6 & 12.0 & 18.4 & Sandy loam & 1.66 \\
\hline $114-200$ & 69.6 & 12.0 & 18.4 & Sandy loam & 1.54 \\
\hline \multirow[t]{2}{*}{ Mean } & 69.6 & 12.6 & 17.8 & & 1.54 \\
\hline & & Middle Slope & & & \\
\hline $0-31$ & 63.6 & 14.0 & 22.4 & Sandy loam & 1.43 \\
\hline $31-68$ & 17.6 & 20.0 & 62.4 & Silty loam & 1.20 \\
\hline $68-112$ & 57.6 & 16.0 & 26.4 & Sandy loam & 1.40 \\
\hline 112-149 & 63.6 & 14.0 & 22.4 & Sandy loam & 1.44 \\
\hline $149-200$ & 17.6 & 22.0 & 60.4 & Silty loam & 1.20 \\
\hline \multirow[t]{2}{*}{ Mean } & 44.0 & 17.2 & 38.8 & & 1.33 \\
\hline & & Lower Slope & & & \\
\hline $0-17$ & 33.6 & 18.0 & 48.4 & Loam & 1.27 \\
\hline $17-58$ & 17.6 & 18.0 & 64.4 & Silty loam & 1.19 \\
\hline $58-112$ & 24.6 & 16.0 & 59.4 & Silty loam & 1.22 \\
\hline $112-148$ & 25.6 & 26.0 & 48.4 & Loam & 1.25 \\
\hline Mean & 25.2 & 19.5 & 55.2 & & 1.23 \\
\hline$S D$ & 22.29 & 3.51 & 18.75 & & 0.16 \\
\hline$C V(\%)$ & 48 & 21 & 50 & & 12 \\
\hline
\end{tabular}

The result of bulk density ranged from 1.19 to $1.66 \mathrm{~g} / \mathrm{cm}^{3}$ (mean $=1.4 \mathrm{~g} / \mathrm{cm}^{3}$ ) across the toposequence. The values of bulk density obtained in this study are within the range reported in earlier findings by [31], who recorded values of 1.11 to $1.98 \mathrm{~g} / \mathrm{cm}^{3}$, while working on floodplain soils in Southern Guinea Savanna of North Central Nigeria. Also the bulk densities of the studied soils showed an apparent increase with depth, this could be attributed to OC distribution down the profile. However the values obtained in these studies are generally considered to be safe for root penetration because penetration might be hindered in soil having bulk density value $>1.75 \mathrm{~g} / \mathrm{cm}^{3}$ $[32,33]$. Donahue et al. [34] pointed out that good plant growth is best at bulk densities below $1.40 \mathrm{~g} / \mathrm{cm}^{3}$ for Clay, and $1.60 \mathrm{~g} / \mathrm{cm}^{3}$ for Sandy soils.

The coefficient of variation for sand and silt recorded a high variability $>35 \%$, while clay and $\mathrm{BD}$ were found to be moderate (Table 2) along the toposequence. This results indicate that toposequence influence the content and distribution of soil physical properties, such as sand and silt.

\section{Chemical properties of Soils of the Study Area}

The mean $\mathrm{pH}$ of the studied soils (Table 3) ranges from 5.52-5.73(mean= 5.52) across the profiles indicating that the soils were moderately acidic [15]. The low $\mathrm{pH}$ values recorded in this study are similar to those earlier reported by $[35,36]$. The acidic condition of the soils under study could be attributable to greater oxidation of anions like sulphides and nitrites leading to soil acidification [21].
Table-3: Chemical Properties of soils of of study area

\begin{tabular}{|l|l|l|l|l|}
\hline $\begin{array}{l}\text { Depth } \\
(\mathbf{c m})\end{array}$ & $\begin{array}{l}\mathbf{p H} \\
\mathbf{( 1 : 2 )}\end{array}$ & $\begin{array}{l}\mathbf{O . C} \\
\mathbf{( g / k g})\end{array}$ & $\begin{array}{l}\mathbf{T N} \\
(\mathbf{g} / \mathbf{k g}\end{array}$ & $\begin{array}{l}\mathbf{A P} \\
(\mathbf{m g} / \mathbf{k g})\end{array}$ \\
\hline & & Upper Slope & & \\
\hline $0-15$ & 5.5 & 0.26 & 0.02 & 7.27 \\
\hline $15-42$ & 5.8 & 0.28 & 0.02 & 6.99 \\
\hline $42-83$ & 5.5 & 0.30 & 0.02 & 6.72 \\
\hline $83-114$ & 5.5 & 0.24 & 0.02 & 6.96 \\
\hline $114-200$ & 5.3 & 0.29 & 0.02 & 6.75 \\
\hline Mean & $\mathbf{5 . 5 2}$ & $\mathbf{0 . 2 7}$ & $\mathbf{0 . 0 2}$ & $\mathbf{6 . 9 4}$ \\
\hline & & Middle Slope & & \\
\hline $0-31$ & 5.8 & 0.25 & 0.02 & 6.63 \\
\hline $31-68$ & 5.5 & 0.34 & 0.03 & 6.91 \\
\hline $68-112$ & 5.8 & 0.33 & 0.03 & 6.99 \\
\hline $112-149$ & 5.8 & 0.26 & 0.02 & 6.55 \\
\hline $149-200$ & 5.7 & 0.34 & 0.03 & 7.03 \\
\hline Mean & $\mathbf{5 . 7 2}$ & $\mathbf{0 . 3 0}$ & $\mathbf{0 . 0 3}$ & $\mathbf{6 . 8 2}$ \\
\hline & & Lower Slope & & \\
\hline $0-17$ & 5.9 & 0.31 & 0.03 & 6.79 \\
\hline $17-58$ & 5.7 & 0.34 & 0.03 & 6.72 \\
\hline $58-112$ & 5.6 & 0.32 & 0.03 & 6.89 \\
\hline $112-148$ & 5.7 & 0.34 & 0.03 & 7.27 \\
\hline Mean & $\mathbf{5 . 7 3}$ & $\mathbf{0 . 3 3}$ & $\mathbf{0 . 0 3}$ & $\mathbf{6 . 9 2}$ \\
\hline SD & $\mathbf{0 . 1 2}$ & $\mathbf{0 . 0 3}$ & $\mathbf{0 . 0 0 6}$ & $\mathbf{0 . 0 6}$ \\
\hline CV(\%) & $\mathbf{2}$ & $\mathbf{1 0}$ & $\mathbf{2 0}$ & $\mathbf{0 . 8}$ \\
\hline & & & &
\end{tabular}

The mean values of organic carbon content ranges from $0.27-0.33 \mathrm{~g} / \mathrm{kg}$ (Table 3 ) across the profiles, and was rated low [15]. The organic carbon was also found to decrease down the slope. This finding is in line to earlier findings by [35, 37] who obtained low OC content for soils in the Savanna zones of Nigeria. The low level of organic carbon in these soils could be attributed to low organic matter returns and other human factors such as crop residue removal, burning 
and mineralization. The total nitrogen content mean value across the profiles ranges from $0.02-0.03 \mathrm{~g} / \mathrm{kg}$ (Table 3) and were rated low as per [15] rating scale. Low total nitrogen in soils has been reported by [38, 39]. The low level of TN obtained in this study could be attributed to TN been mobile in soils, as a result its losses through various mechanism like ammonia volatilization especially under high temperature that characterize the climate of the region, succeeding denitrification, chemical and microbial fixation, leaching and runoff all results in residual/available $\mathrm{N}$ to be poor in soils [30]. The mean values of available phosphorus ranges from $6.82-6.94 \mathrm{mg} / \mathrm{kg}$ (Table 3) across the profile and were rated medium according to [15]. Such low available $P$ values were earlier reported by $[25,40]$ in their various findings [41] attributed the low value of available phosphorus as recorded in this study to its low content in the parent materials and its propensity to sorption on mineral surface. It could also be due to fixation, as a result of the acidic condition of the soils.

Also the coefficient of variation of soil chemical properties (Table 3) along the toposequence, showed that variability in soil $\mathrm{pH}(2 \%)$ and $\mathrm{Ap}(0.8 \%)$ were found to be low, while OC (10\%) and TN (20\%), showed moderate variability. This finding indicated that toposequence only influences the content and distribution of soil OC and TN.

\section{Properties of Soils Exchangeable bases of the Study Area}

The exchangeable bases ( $\mathrm{Ca}, \mathrm{Mg}, \mathrm{Na}$ and $\mathrm{K}$ ) content in the soil profiles across the toposequence are presented in Table 4. The mean values of exchangeable calcium content ranges from $4.18-10.1 \mathrm{cmol}(+) / \mathrm{kg}$ across the profiles (Table 4), and were rated medium to high [15]. Also the exchangeable calcium content in this study is the dominant cation on the exchange sites of the studied soils (Table 4). This is in line with earlier findings by several researchers [42, 43, 39] who reported the preponderance of $\mathrm{Ca}$ over other cations. The dominance of $\mathrm{Ca}$ over other cations may be due to the existence of calcium bearing parent material [18]. The mean exchangeable magnesium content values ranges from 2.84 to $3.30 \mathrm{cmol}(+) / \mathrm{kg}$ across the profiles, with higher values obtained at the upper slope (Table 4). As per [15] rating scale this values are rated high. Magnesium (Mg) is the second most dominant extractable cation on the exchange complex of the studied profiles. The values of exchangeable $\mathrm{Mg}$ content in the soils across the various sampling units and depth ranged from 0.41 to $4.11 \mathrm{cmol}(+) / \mathrm{kg}$ soil (Table 4), and was rated medium to high [15, 44], also encountered high $\mathrm{Mg}$ soil content in his assessment of Some Soil Fertility Characteristics of Abakaliki Urban FloodPlains of South-East Nigeria. This seemingly medium to high value of $\mathrm{Mg}$ content obtained in this study could be related to the calcareous nature of the parent material [45]. The sodium content of the studied soil range from $0.09-0.15 \mathrm{cmol} / \mathrm{kg}$ across the profiles (Table 4) was found to be medium to high [15]. Similar values were earlier reported by [46, 44, 47], also reported sodium content values ranging from 0.14 to $2.34 \mathrm{cmol}(+) / \mathrm{kg}$ soil, while working on Vertisols [44] attributed this high value of $\mathrm{Na}$ to deposition of salts on the soil as the flood water recedes, leaving salt crusts and crystals upon evaporation, while [46] attributed it to the nature of parent material (colluvia and alluvia) and use of low quality water for irrigation.

Table-4: Exchangeable Bases of soils of study area

\begin{tabular}{|c|c|c|c|c|}
\hline Depth (cm) & $\mathbf{C a}$ & Mg $\quad \mathrm{cmol} / \mathrm{kg}$ & $\mathbf{N a}$ & $\mathbf{K}$ \\
\hline & & \multicolumn{2}{|l|}{ Uppers Slope } & \\
\hline $0-15$ & 5.60 & 2.35 & 0.22 & 0.18 \\
\hline $15-42$ & 7.20 & 2.67 & 0.22 & 0.18 \\
\hline $42-83$ & 4.00 & 3.83 & 0.09 & 0.36 \\
\hline $83-114$ & 1.68 & 3.11 & 0.09 & 0.49 \\
\hline $114-200$ & 2.40 & 4.56 & 0.21 & 0.21 \\
\hline \multirow[t]{2}{*}{ Mean } & 4.18 & 3.30 & 0.15 & 0.28 \\
\hline & & \multicolumn{2}{|l|}{ Middle Slope } & \\
\hline $0-31$ & 12.00 & 3.10 & 0.04 & 0.23 \\
\hline $31-68$ & 4.00 & 2.83 & 0.09 & 0.41 \\
\hline $68-112$ & 4.80 & 2.07 & 0.09 & 0.26 \\
\hline $112-149$ & 9.84 & 2.91 & 0.09 & 0.54 \\
\hline $149-200$ & 7.20 & 3.28 & 0.13 & 0.08 \\
\hline \multirow[t]{2}{*}{ Mean } & 7.57 & 2.84 & 0.09 & 0.30 \\
\hline & & \multicolumn{2}{|l|}{ Lower Slope } & \\
\hline $0-17$ & 11.20 & 3.64 & 0.09 & 0.56 \\
\hline $17-58$ & 10.00 & 2.43 & 0.04 & 0.10 \\
\hline $58-112$ & 8.80 & 3.88 & 0.17 & 0.31 \\
\hline $112-148$ & 10.40 & 2.48 & 0.13 & 0.36 \\
\hline Mean & 10.10 & 3.10 & 0.11 & 0.33 \\
\hline$S D$ & 2.97 & 0.23 & 0.03 & 0.03 \\
\hline$C V(\%)$ & 41 & 8 & 25 & 10 \\
\hline
\end{tabular}


The mean potassium content of the studied soils ranges from $0.28-0.33 \mathrm{cmol} / \mathrm{kg}$ across the profiles (Table 4) and were found to be medium to high as per [45] rating scale. In this study, the exchangeable $\mathrm{K}$ values between sampling units and horizons of the soils (Table 4) ranged from 0.36 to $0.56 \mathrm{cmol}(+) / \mathrm{kg}$ and were rated high according to [15] rating scale [37], also reported high $\mathrm{k}$ values while assessing variation in soil exchangeable bases along toposequences, in Gombe State, Nigeria. This medium to higher available potassium content observed in this study may be attributed to more intense weathering, release of labile $\mathrm{K}$ from organic residue and by the application of chemical fertilizers containing $\mathrm{K}$ [48]. The value greater than $2 \mathrm{cmol}(+) / \mathrm{kg}$ of $\mathrm{K}$ in soil indicates a fairly good supply and the response to $\mathrm{K}$ fertilizer is unlikely [49, 50].

The coefficient of variation of soil exchangeable bases (Table 4) along the toposequence, showed that $\mathrm{Mg}(8 \%)$, recorded low variation, while $\mathrm{Na}$ $(25 \%)$ and $\mathrm{K}(10 \%)$ recorded low variability. The variability for $\mathrm{Ca}(41 \%)$ was found to be very high. This is an indication that of all the exchangeable bases only $\mathrm{Ca}$ is found to be highly influenced by the geomorphic nature of the study area.

\section{CONCLUSIONS}

Based on the result of the study, the result indicated that most of the soils are predominantly weakred to pale-red in colour (7.5R 4/3 - 10R 7/3). Sand dominated the particle size distribution and most of the soils are sandy loam to silt loam in texture. From the soils considered, the structure is dominantly subangular blocky in all the profiles. Most of the profiles had friable moist consistence at the top and slightly hard dry consistence at the lower horizon. Also the soils were observed to be moderately acidic, low in OC, TN and AP, while the exchangeable bases were also found to be generally medium to high. The results further indicated that soil properties, such as Sand, Clay, Silt, $\mathrm{TN}, \mathrm{Ca}$ and $\mathrm{Na}$ are found to be variable and could easily be influenced by differences in physiographic positions.

\section{RECOMMENDATIONS}

In line with the above findings there is need to adopt the appropriate agronomic measures for a sustainable agricultural production, within the study area. Management practices such as mulching cover cropping, alley cropping, addition of organic and green manures, chemical fertilizers containing especially $\mathrm{N}$ and $\mathrm{P}$ should be adopted. Finally proper and periodic monitoring of the physical and chemical properties of such soils is very necessary, so that appropriate and preventive measures could be embarked upon as and when due, for optimum agricultural productivity.

\section{REFERENCES}

1. Murwira HK, Kumwenda JD, Hikwa D, Tagwira F. Soil fertility research for maize-based farming systems in Malawi and Zimbabwe. CIMMYT; 1998.

2. Mukungurutse, S. Collis, Newton Nyapwere, Amos M. Manyanga and Luke Mhaka. Pedological Characterization and Classification of Typical Soils of Lupane District, Zimbabwe. International Journal of Plant and Soil Science.2018; 22(3): 1-12

3. Sharu MB, Yakubu M, Noma SS, Tsafe AI. Characterization and classification of soils on an agricultural landscape in Dingyadi District, Sokoto State, Nigeria. Nigerian Journal of Basic and Applied Sciences. 2013; 21(2):137-147.

4. Karuma AN, Gachene K, Charles K Msanya BM, Mtakwa PW, Amuri N, Gicheru PT. Soil morphology, physicochemical properties and classification of typical soils of Mwala District, Kenya. International Journal of Plant \& Soil Science. 2015; 4(2):156-170.

5. Kebeney SJ, Msanya, BM, Ng'etich WK, Semoka JM, Serrem CK. Pedological characterization of some typical soils of Busia County, Western Kenya: Soil morphology, physico-chemical properties, classification and fertility trends. International Journal of Plant \& Soil Science. 2015; 4(1):29-44.

6. Ikusemoran, Mayomi, Didams, Gideon and Michael, Abashiya. Analysis of the Spatial Distribution of Geology and Pedologic Formations in Gombe State, North Eastern Nigeria. Journal of Geography and Geology. 2018;10 (1):83-108

7. Abubakar BY. North-east economic summit: Upscaling agricultural-business in the North-east through innovative value and agricultural clusters. A paper presented by the executive secretary, agricultural research council of Nigeria at a workshop organized by the agricultural research council of Nigeria at Mabushi Abuja between 3rd and 4th Dec. 2013.

8. UBRBDA. Upper Benue River Basin Development Authority Metrological Unit. Dadin kowa Substation, Gombe State, Nigeria; 2018.

9. Agbenin JO. Laboratory manual for soil and plant analysis (Selected Methods and data analysis). Department of soil science, ABU Zaria. 1995;140

10. Black GR and Hartge KH. Particle density. In: Klute. A (ed) methods of soil Analysis part 1, physical and mineralogical methods. Agron. 9 ASA. INC. Madison. W. E. USA.1986; 377-382.

11. Page, AL, Miller RH and Kenny DR. Method of soil analysis, part II Agronomy No 9 ASA Madison, Wisconsin, 1982; 2

12. Black CA. Methods of soil analysis. Part I, American Society of Agronomy. Madison, Wisconsin, USA.1965; 1572.

13. Harry F and CA Steven. Statistics: Concepts and Applications. Cambridge Univ. Press, Great Britain. 1995; 853. 
14. Wilding LP. Spatial variability: Its documentation, accommodation and implication to Soil Survey. In: Soil Spatial Variability. Nielsen D.R., Bouma, J. (Eds) Pudoc. Wageningen. The Netherlands. 1985; 166-194.

15. Malgwi WB. Soil Survey: Soil Analytical Data Interpretation for Land Management. Paper presented at Training Workshop in Soil Survey and Land Evaluation Methodology for Federal Department of Agriculture and Land Resource Staff in Kaduna; 2007.

16. Zata AI. The Study of Soils Derived from Olivine Basaltic Deposits of Lunguda Plateau (A): Morphological Properties of Vertisols. Journal of League of Researchers of Nigeria. 2010;11(2):1018.

17. Zata AIA. Ibrahim and S. Mustapha. A Detailed Soil Survey and Characterization of Some Usterts in Northeastern Nigeria. Journal of Emerging Trends in Engineering and Applied Sciences. 2013; 4(4): 552-556.

18. Nahusenya A, Kibebew K, Heluf G and Abayneh E. Characterization and classification of soil along the toposequence at the Wadla Delanta Massif, North Central Highlands of Ethiopia. Journal of Ecology and the Natural Environment. 2014; 6(9):304-320

19. Alem H, Kibebew K, Heluf G. Characterization and classification of soils of Kabe Subwatershed in South Wollo Zone, Northeastern Ethiopia. African Journal of Soil Science. 2015; 3(7): 134-146.

20. Ahukaemere CM, Onweremadu EU, Akamigbo FOR and Ndukwu BN. Suitability evaluation of soils of the coastal plain sands for rainfed maize production in acid sands of south eastern Nigeria. Nigerian Journal of Soil Science. 2016; 26: 138145

21. Ahukaemere CM, Eshett $\mathrm{E} \mathrm{T}$ and Ahiwe $\mathrm{C}$. Characterization and fertility Status of wetland Soils in Abia State agro-ecological zone of Southeastern Nigeria. Nigerian Journal of Soil Science. 2014; 24(1): 147 -157.

22. Hussaini GM. Land Suitability Evaluation for Some Selected Land Use Type in the Institute for Agricultural Research Farm, Zaria, Nigeria. Unpublished M.Sc. Thesis. Department of Soil Science, ABU, Zaria; 2011.

23. Fekadu, Endalkachew, Kibebew Kibret, Bobe Bedadi, Asmare Melese. Characterization and classification of soils of Yikalo Subwatershed in Lay Gayint District, Northwestern Highlands of Ethiopia. Eurasian Journal of Soil Science. 2018; 7(2) $151-166$

24. Shobayo AB. A lithosequence of soils developed on basement complex rocks of zaria, the northern guinea savanna, nigeria. Unpublished MSc. Thesis. Dept. of Soil Sci, ABU, Zaria; 2010.

25. Imadojemu PE, Osujieke DN and Obasi SN. Evaluation of fadama soils along a toposequence proximal to river donga in Wukari area of
Northeast Nigeria. International Journal of Agriculture and Rural Development.2017; 20(2): 3150-3158.

26. Askira MS, Musa H and Salem A. Assessment of physical and chemical properties of soils of Iware, Ardo-kola Local Government Area, Taraba State, Nigeria. Biological and Environmental Sciences Journal for the Tropics. 2019;16(1):1 - 10

27. Askira MS, Musa $H$ and Salem A. Fertility Evaluation under different Management Practices in Fufore Local Government Area of Adamawa state, Nigeria. Biological and Environmental Sciences Journal for the Tropics.2019; 16(1):27 32

28. Maniyunda LM. Pedogensis on Loess and Basement Complex rocks in a subhumid environment of Nigeria and the suitability of the lands for rainfed cultivation. An unpublished M. Sc Thesis submitted to Soil Science Department, Ahmadu Bello University, Zaria; 1999.

29. Mukungurutse CS, Nyapwere N, Manyanga AM, Mhaka L. Pedological Characterization and Classification of Typical Soils of Lupane District, Zimbabwe. International Journal of Plant and Soil Science. 2018;22(3):1-2.

30. Akpan JF, Aki EE and Isong IA. Comparative Assessment of Wetland and Coastal plain Soils in Calabar, Cross River State. Global journal of agricultural sciences. 2017; 16:17-30

31. Ande, OT, Are KS, Adeyolanu OD, Ojo OA, Oke AO, Adelana AO, Adetayo AO, Oluwatosin GA. Characterization of floodplain soils in Southern Guinea Savanna of North Central Nigeria. Catena.2016; 139: 19-27

32. Esu IE. Characterization, classification and management problems of the major soil orders in Nigeria. 26th Inaugural Lecture of the University of Calabar; 2005.

33. Ashenafi A, Abayneh E, Sheleme B. Characterizing soils of Delbo Wegene watershed, Wolaita Zone, Southern Ethiopia for planning appropriate land management. Journal of Soil Science and Environmental Management. 2010; 1: 184-199.

34. Donahue RL, Raymond MW and Schick Line JC. Soils: An introduction to soils and plant growth. Prentice hall of India. 1990; 667

35. Abagyeh SOL, Wuese ST and Ezenwa MIS. Characterisation, Classification and Management of Integrated Landscapes in the Middle Benue Valley of Benue State. Nigerian Journal of Soil Science. 2017; 27:267-281.

36. Okoli NH, Uzoho BU, Onweremadu EU, Ahukaemere CM, Osisi AF and Aliba EO. Status and Available Micronutrients in Soil Profiles of different Parent Materials in Imo State, Southeastern, Nigeria. Nigerian Journal of Soil Science. 2017; 27:40-52.

37. Salem A, Dedan NK and Ibrahim AE. Geospatial Variation in Soil Exchangeable Bases along 
Toposequences, in Gombe State, Northern Guinea Savanna Zone of Nigeria. Journal of Agriculture, Food Security and Sustainable Environment. 2018; 1(1): 71-78

38. Musa H, Salem A and Askira MS. Soil Profile Characteristics under Cultivated and Uncultivated Areas of Garkida, Adamawa State, Nigeria. Nigerian Journal of Engineering, Sciences and Technological Research.2017; 3(2): 68-79. Musa $\mathrm{H}$, Salem A and Askira MS. Profile Characterization of Soils of Iware, Ardo-Kola Local Government Area of Taraba State, Northern Guinea Savanna Ecological Zone of Nigeria. Savannah Journal of Agriculture. 2017;12(2): 5360.

39. Kebede M, Shimbir T, Kasa G, Abera D, Girma T. Description, characterization and classification of the major soils in Jinka Agricultural Research Center, South Western Ethiopia. Journal of Soil Science and Environmental Management. 2017; 8(3): 61-69.

40. Piccolo A and Gobena H. Phosphorus status of some Ethiopian soils. Journal of Tropical Agriculture.1986; 63: 137-142.

41. Adisa KF, Ojetade JO, Muda SA and Amusan AA. Characterization and fertility capability classification of the soils of shasha river floodplain, osun state, Nigeria. Ife Journal of Agriculture. 2016; 28(1); 20-34.

42. Kefas PK, Ukabiala, ME, Azuka CV. The physical properties and micronutrient status of Mayo-gwoi floodplain soils, in Taraba State, Nigeria. International Journal of Plant and Soil
Science. 2016; 10(6):1-8.

43. Ogbodo EN. Assessment of Some Soil Fertility Characteristics of Abakaliki Urban Flood Plains of South-East Nigeria, for Sustainable Crop Production. World Journal of Agricultural Sciences. 2011; 7 (4): 489-495.

44. Havlin JL, Beaton JD, Tisdale SL and Nelson WL. Soil fertility and fertilizers. Pearson education Inc. Singapore. 1999; 499.

45. Babalola TS, Oso T, Fasina AS and Godonu K. Land Evaluation Studies of two Wetland Soils in Nigeria. International Research Journal of Agricultural Science and Soil Science. 2011; 1(6): 193-204

46. Gokhan $\mathrm{O}$ and Ertugrul A. Characterisation, classification and agricultural Usage of vertisols developed on neogen aged calcareous marl parent materials. Journal of Biological and Environmental Sciences. 2007; 1(1): 5- 10.

47. Sai Kumar R, Satish Kumar YS and Srinivas P. Characterization, Classification and Evaluation of Chilli Growing Soils Of Khammam District, Andhra Pradesh. International Journal of Innovative Research and Development. 2013;2(9): 26-33.

48. Finck A. Kalium statues of some Sudan clay soils. Plant and Soil.1962; 16: 293-309.

49. Finck A and Venkateswarlu J. Chemical properties and fertility management of Vertisols. In: Vertisols and Rice Soils of the tropics. Symposia Papers II, $12^{\text {th }}$ International Congress of Soil Science, New Delhi, India. 1982: 61-79. 